\title{
Differences in Regulation of Emotions Based on Age Range and Gender in Adolescents at Uswatun Khasanah Orphanage Samarinda
}

\author{
Muhammad Bachtiar Safrudin ${ }^{1}$ \\ ${ }^{1}$ Department of community nursing, Faculty of Nursing, University of Muhammadiyah East \\ Kalimantan, Indonesia \\ *Coresponding author: mbs143@umkt.ac.id
}

\begin{abstract}
Adolescence shows changes in emotional characteristics that tend to be unstable, where adolescence is considered a period of hurricane storms. Changes in the stages of this developmental body when viewed from the characteristics, it is not known for sure whether there are differences between groups of male and female adolescents and the age level (early, middle and late) in these adolescents. This study aims to describe the picture and determine the differences in emotional regulation in terms of gender and age range in adolescents at the Uswatun Khasanah Orphanage in Samarinda. The research respondents were 104 which were divided by gender and age range. This study uses emotion regulation instruments that refer to standard research and tools. This research approach uses quantitative descriptivecomparative research. The results showed that there were differences in the emotional regulation of gender in adolescents at the Uswatun Khasanah in Samarinda orphanage with a value of sig ( 2 tailed $)=$ 0.000 . Other results show that there are differences in emotional regulation with values of sig $(2$ tailed $)=$ $0.005,0.001$ and 0.000 in terms of the age range of early, middle and late adolescents at the Uswatun Khasanah Orphanage. Recommendations for further research to compare groups of adolescents who are in orphanages and adolescents who live with their parents, with a larger and more evenly distributed number of respondents, are important suggestions for future research.
\end{abstract}

Keywords: Adolescents in orphanage, emotion regulation, gender and age range

\section{Introduction}

Adolescence is part of an important life stage in the cycle of individual development which is a transitional period that can be directed to the development of healthy adulthood. Adolescent developmental tasks must be completed properly so that problems in development do not experience difficulties (Ali, 2015; Sahputra et al., 2017)

According to the Central Statistics Agency (BPS) the number of teenage boys aged 10-19 years in 2017 was 98.50 people and teenage girls aged 10-19 years 96.92 people, in 2018 the number of boys aged 10-19 years was 97, 50 people and young women aged 10-19 years amounted to 96.93 people, in 2019 the number of teenage boys aged 10-19 years was 98.59 people and teenage girls aged 10-19 years amounted to 97.25 people (BPS, 2020).

Adolescents enter a period of transition from children to mature characters or adulthood. Characteristics of adolescent children will tend to be independent individuals with the desire to be able to voice their rights in expressing ideas or opinions (Umami, 2019). Another characteristic that is identical at the adolescent stage is closeness to peers (Santrock, 2015). In addition, adolescents experience physical changes in both growth and sexuality. When teenagers 
enter puberty, an attitude will appear in showing flexibility and expressing their thoughts (AzZa'balawi, 2017).

Family involvement in controlling and becoming a bulwark equips adolescents to be able to carry out their developmental tasks greatly determines the characteristics of adolescents in later life (Gunarsa, 2018; Muri'ah \& Wardan, 2020). The family environment is the initial and main learning stage. The lessons learned for children include faith, social, and how to interact with their environment. Together with the family, the teenager will show his first opinion, like something that is not inside him(Ali, 2015; Gunarsa, 2018; Hurlock et al., 2015; Jahja, 2011; Muri'ah \& Wardan, 2020).

The interaction of parents and adolescents is very influential on their growth and development. Where a good relationship can affect various aspects of the stages of growth and development (Hurlock et al., 2015; Saputro, 2018; Soetjiningsih, 2018). If the role of the family does not go well, it will have a serious impact on adolescent problems. At this time, adolescents will be more stubborn and their emotions will deteriorate, as a result it is difficult to absorb the direction and reprimands of fathers and mothers (Umami, 2019). For this reason, the role of the family is very much needed in supporting the development of children when they enter their teens (Putro, 2017).

According to WHO (2015) until now, adolescent problems have received less attention than children, family and women's health, and welfare (WHO, 2015). According to Prasetyanti (2019), the behavior of teenagers today is very worrying, this is indicated by the increasing number of cases such as abortion, unwanted pregnancy (KTD), and sexually transmitted diseases (STDs) including HIV/AIDS (Seputra, 2020). Emotion regulation includes the ability to control emotional status and behavior as a way of expressing emotions to suit the surrounding environment (Thompson, 2014). The results of this study are supported by Morris, et al. (2017) which states that emotion regulation has an impact on a person's social competence (Morris et al., 2017). The individual's ability to manage emotions will result in the individual being able to deal with tensions in his life.

Lack of fulfillment of psychological needs, children who live in orphanages usually experience psychological disorders. The results of Mulyati's research (2017) show that orphanages act as a substitute for families in meeting the needs of children in their development process, however, several studies have shown that adolescents who live in orphanages are more susceptible to psychological disorders (Mulyati, 2017). According to Diener, et al (2017), it shows that the children living in the orphanage are not prosperous, both emotionally, psychologically and socially (Diener et al., 2017).

Emotional regulation is influenced by various factors, namely factors that come from outside the individual to the ability of the individual itself. Some of these factors include: (a) the relationship between parents and children; (b) age and gender; (c) interpersonal relationships (Zonya, O. L \& Sano, 2019). Based on these references, one of the factors that influence a person's emotional regulation is gender. Women are said to be more emotional than men. This is evidenced by several studies indicating that women are more emotionally responsive than men. 
Another factor that affects emotion regulation is the level of age with increasing age it will increase the ability to regulate emotions (Illahi et al., 2018). The higher the age of the individual, the better the ability to regulate emotions (Bradley et al., 2017). This is in line with the results of research that age also affects the regulation of one's emotions (Lucas \& Gohm, 2016). This is reinforced by the opinion of Gross (2013) that the older you get, the better your emotional regulation will be (Gross \& John, 2013). Another study conducted by Novitasari (2016) showed that students with high emotional regulation have the characteristics of being able to deal with problems more calmly, more able to control themselves and have the ability to build their personality.

There are so many benefits that can be felt by individuals in emotion regulation, especially by final year students. Gottman (1997, in Sari 2020) states that applying emotion regulation in everyday life will have a positive impact both on physical health, academic success, ease in fostering relationships with others and increase resilience or resistance to stressful conditions. Research results that show a positive relationship are possible because aspects of emotional regulation are related and have an influence on aspects of resilience, including suppression or refraining from bringing up emotional reactions that affect perseverance and persistence in facing difficulties (Sari et al., 2020)

Preliminary study conducted at the Uswatun Hasanah orphanage from 5 respondents who conducted measurements related to emotional regulation where 2 respondents said they could not control feelings when they were happy or sad, 3 respondents said they would show when they are emotional or face a stressor which will show when they are feeling upset, 1 person said he cursed if he was having problems with friends, 4 people said it was difficult to concentrate when he was facing a problem, and as many as 3 people said when he was sad he became lazy to do any activities. It can be concluded from the 5 respondents who were interviewed in a structured manner, they showed that they had emotional regulation disorders.

From the results of the preliminary study and no research has ever been done regarding emotional stimulation at the Uswatun Khasanah orphanage Samarinda, the researchers are interested in raising the theme with the title "Differences in Emotion Regulation Based on Age Range and Gender in Adolescents at Uswatun Khasanah Orphanage Samarinda".

\section{Materials and Methods}

Materials and methods should describe complete material applied in the study. Method should contain all steps and rule that used, include the procedure clearly. New method, new procedure or new treatment could be cited from previous researcher that available on the field. Study about animal or human need requirement to provide ethical approval. 


\section{Results and Discussion}

\subsection{Results}

This study aims to: (1) determine the description of emotion regulation by gender; (2) Knowing the description of emotion regulation based on the level of adolescent age: early, middle and late; and (3) To find out the differences in the emotions of adolescents from gender and gender level. The analysis shows the following results:

\subsubsection{Regulation of Emotions by Gender}

Table 1. Description of Regulation Based on Gender Emotions

\begin{tabular}{clcc}
\hline \multicolumn{1}{c}{ Gender } & Emotion regulation category & $\mathrm{N}$ & Percantage (\%) \\
\hline Male & Tall & 69 & 61,53 \\
& Low & 45 & 43,23 \\
\hline \multirow{2}{*}{ Female } & Tall & 50 & 48,07 \\
& Law & 54 & 51,92 \\
\hline
\end{tabular}

Table 1 shows that male adolescents have high emotional regulation of 69 respondents $(61.53 \%)$ and female adolescents have low emotional regulation of 54 respondents $(51.92 \%)$. Higher percentage in emotion regulation.

Table 2. Differences in Regulation Based on Gender Emotions

\begin{tabular}{lccc}
\hline Gender & Mean & SD & p-value \\
\hline Male & 65.34 & 9.087 & 0.000 \\
Femal & 54.40 & 8.235 & \\
\hline
\end{tabular}

Table 2 shows that adolescents male have an average score of 65.34 with a standard deviation of 9.087 and female have an average score of 54.40 with a standard deviation of 8.235. The results of the hypothesis test prove that there is no difference in emotion regulation in terms of gender in adolescents. This is indicated by the results of the twotailed hypothesis test, which obtained a significance of $0.000(\mathrm{p}>0.05)$, so the initial hypothesis proposed in this study was accepted because there were differences in the emotional regulation of male and female.

\subsubsection{Regulation of Emotions by Level Age}

Table 3. Description of Regulation Based on Level Age Emotions

\begin{tabular}{llcc}
\hline Level Age & Emotion regulation category & N & Percantage (\%) \\
\hline Early & Low & 51 & 49,03 \\
Midlle & Low & 55 & 52,88 \\
Late & Tall & 62 & 59,61 \\
\hline
\end{tabular}

Table 3 provides information that based on descriptive analysis at each level of early adolescence with low emission regulation category, it is known that 51 respondents (49.03\%) respondents, 55 respondents (52.88\%) middle adolescents with low emotional regulation category. and late teens as many as 62 respondents $(59.61 \%)$ in the category of high emotional regulation. 
Table 4. Differences in Regulation Based on Level Age Emotions

\begin{tabular}{lccc}
\hline Level Ages & Mean & SD & p-value \\
\hline Early Adolescents & 56.53 & 11.495 & 0.005 \\
Midle Adolescents & 65.57 & 7.180 & 0.001 \\
Late Adolescents & 65.87 & 8.515 & 0.000 \\
\hline
\end{tabular}

Table 4 explains that the results of descriptive analysis based on age level also show that adolescents who are in the early phase have an average score of 56.53 with a standard deviation of 11,495, adolescents who are in the middle phase have an average score of 65.57 with a standard deviation of 7,180 and adolescents which is in the final phase has an average score of 65.87 with a standard deviation of 8,515 . This means that the difference in age will have an impact on emotion regulation, especially the difference between early adolescence and late adolescence is more striking.

Based on the results of hypothesis testing in this study, it is proven that overall there are differences in emotional regulation in terms of the age range (early, middle and late) with p-values $(0.005 ; 0.001$ and 0.000$)$. This means that there are differences in the level of emotional regulation between early and middle adolescents, there are differences in emotional regulation of early and late adolescents and there are differences in emotional regulation of middle and late adolescents.

\subsection{Discussion}

\subsubsection{Regulation of emotions by gender}

The results of this study indicate that the majority of the male group's emotional regulation is in the high category while the female group is in the low category. One of the factors that influence emotion regulation by gender. Gender Women are said to be more emotional than the male gender. The results of research showed that the emotional regulation of male students was generally in the medium category and emotional regulation of the female group was in the low category (Zonya, O. L \& Sano, 2019).

This is evidenced by several studies indicating that women are more emotionally responsive than men (Bradley et al., 2017; Lucas \& Gohm, 2016; Santrock, 2015; Seidlitz \& Diener, 2018). Different research conducted by Brody (2017) explains that related to values and beliefs in society, it shows that women are evidence that women will show more emotional expressions than men (Brody, 2017).

Furthermore, research conducted by Sahputra, et al (2017) shows that good emotional intelligence will indicate a person's ability to regulate emotions and feelings. Furthermore, it is explained that this emotional intelligence will show a person's ability to regulate one's mood, the ability to carry out good social relationships, cheerful character, not easily afraid of stressful situations faced and able to control negative thoughts (Sahputra et al., 2017). According to Illahi et al (2018) explaining emotional intelligence is a person's ability to analyze the situation at hand before taking an action 
where someone will think about the possible risks of the action to be taken and be more able to control the emotional aspect (Illahi et al., 2018).

In the aspect of emotional control, it shows different results between men and women where the strategy aspect shows that women are better than men, the involvement aspect shows a moderate category between male and female, the control aspect of male and female students is also the same. Same is in the midle category, the highest acceptance is owned by female students in the medium category. The assumption that the researcher can explain from the results of this study shows that the regulation of emotions between male and female has a significant difference. The boy group was better at emotion regulation than the girl group. The group of adolescent female is more responsive in controlling emotions and this is related to the management of stress and the response made by adolescent female compared to the male group.

The results showed that there were differences in emotional regulation in terms of gender in adolescents with at the orphanage. The results of hypothesis testing obtained a two-tailed significance of 0.000 ( $\mathrm{p}$-value > 0.05). This means that there are differences in the emotional regulation of adolescent girls and boys in orphanages based on gender. The results of this study are in line with previous research that there are differences in emotional regulation between female and male (Ratnasari \& Suleeman, 2017). This is presumably because strategies with suppression increase with age in men, but not in female and the use of acceptance strategies does not decrease with age, especially in female (Nolen-Hoeksema \& Aldao, 2016).

The emotion regulation strategy will be different when the respondent is an adult. This is reinforced by research based on a cross-sectional approach by comparing emotion regulation strategies in adult female respondents. The results showed that older women used less suppression strategies than younger women. So, with increasing age, it will increase reappraisal emotion regulation strategies and reduce the use of suppression strategies (Gross \& John, 2013).

\subsubsection{Regulation of emotions by Level Age}

Based on the results of the study, the majority of high emotion regulation ranged in late adolescence, namely between the ages of 15-20 years. At this stage, adolescents are considered to be experiencing psychological changes, which at this time is considered a period of hurricane storms where there are significant emotional changes. These changes are influenced by physical changes and changes in the glands (Hurlock et al., 2015). The emotional level at this stage will show very large and uncontrollable and irrational emotions which will experience improvement in the seventh year ( $\geq 16$ years) after entering adolescence. This is very clear with the majority of adolescents at the age of 13-15 years as many as 7 adolescents (\%).

According to Zonya and Sono (2019), emotion regulation is influenced by various factors, namely factors that come from outside the individual to the individual's own 
abilities. Some of these factors include: (a) the relationship between the parents and the teenager; (b) the adolescent's interpersonal relationship and (c) age and gender (Zonya, O. L \& Sano, 2019).

According to the results of research on emotion regulation that increasing individual age will be correlated with an increase in the ability of emotion regulation. Therefore the higher an individual's age, the better his emotion regulation ability (Rubiani, 2017). This is in line with the research results of that age also has an effect on the regulation of one's emotions (Silvers et al., 2017). This is reinforced by the opinion of Gross (2014) that the older you get, the better your emotional regulation will be (Gross, 2014).

At this age development, there are special characteristics in adolescents from the perspective of development. In the period of human growth and development, there will be several periods from birth to death. In the stages of growth and development, there will be a link between the stages of growth and development with one another. According to Santrock (2015) explains that the stages of growth and development are risky, where adolescence is a transition period from the childhood stage to the adult stage (Santrock, 2015). At this stage children will experience significant changes, including the ability to control or regulate emotions. The description of emotion regulation in the adolescent age group shows that early and middle adolescents show less emotional regulation than late adolescents.

The results of the first analysis obtained a two-tailed significance of 0.005 between early adolescents and middle adolescents. These results indicate that the initial hypothesis proposed in this study is accepted. In other words, there are differences in emotional regulation between early and middle adolescents. Furthermore, the results obtained a two-tailed significance of 0.001 between early adolescents and late adolescents. Obtained from middle adolescents with late adolescents indicate that the initial hypothesis proposed in this study was rejected because it obtained a two-tailed significance result of 0.000 . This shows that the initial hypothesis in this study is accepted where the hypothesis proposed is that there is a difference in the level of emotion regulation in early adolescence and late adolescence.

The results of the study conducted by Rubiani and Sembiring (2018) stated that there was a difference between emotion regulation in terms of age. The low level of emotion regulation in early and middle level adolescents who are in orphanages is due to the low ability to understand, balance, and measure the level of expressed emotions related to age level. Research on emotion regulation in adolescents proves that the higher the age level, the higher the ability to control emotions. This study proves the emotional regulation of late adolescence is better than the emotional regulation of middle and early adolescents so that it can be concluded that in this study late adolescents have better emotional regulation abilities than early and middle adolescents (Rubiani \& Sembiring, 2018). 
Limitations in this study do not emphasize the measurement of adaptive and maladaptive emotion regulation strategies. Theoretically, generally adaptive forms of emotion regulation such as reappraissal provide benefits related to affective function, social interaction and well-being, whereas expressive suppression has the opposite effect (Gross \& John, 2003). Thus, it is recommended for future research to measure not only emotion regulation, but also emotion regulation strategies (adaptive and maladaptive), to test whether there are differences related to the age range of adolescence (early, middle and late adolescence).

\section{Conclusion}

This study aims to describe the description of emotion regulation by gender; knowing the description of emotion regulation based on the age range of adolescents: early, middle and late teens; and knowing the differences in emotion regulation in terms of gender and age range of adolescents (early teens, middle teens and late teens). This study concludes that most of the male adolescents who are in the orphanage have emotion regulation in the high category, while most of the female adolescents have emotion regulation in the low category. Based on the age range, most of the early and middle adolescents with divorced parents had emotional regulation in the low category, while the late adolescents in orphanages had high emotional regulation; there are differences in emotional regulation in terms of gender in adolescents who live in orphanages. This can be interpreted that in this study gender cannot distinguish the regulatory ability of a person because the scores obtained have very thin (not significant) differences; and based on the age range of adolescents, there are differences in emotional regulation in terms of the age range of adolescents who are in orphanages. This means that the age range can distinguish a person's emotional regulation ability because the scores obtained are quite different.

\section{Acknowledgements}

The researcher would like to thank all those who have helped in the process of this research. To the head of the Khusnul Khatimah orphanage who has given the research permit, all respondents involved in the research and the head of the architectural study program at the Muhammadiyah University of East Kalimantan.

\section{Conflict of Interest}

All Authors declare no conflict of interest and agree with the content of the manuscript.

\section{References}

Ali, H. Z. (2015). Pengantar keperawatan keluarga.

BPS. (2020). Badan pusat statistik : Regulasi Penduduk Tahun 2020. BPS Republik Indonesia.

Bradley, M. M., Codispoti, M., Sabatinelli, D., \& Lang, P. J. (2017). Emotion and motivation II: sex differences in picture processing. Emotion, 1(3), 300.

Brody, L. (2017). Beyond stereotypes: Gender and emotion. Journal of Social Issues, 53, 369393. 
Diener, E., Suh, E., \& Oishi, S. (2017). Recent findings on subjective well-being. Indian Journal of Clinical Psychology, 24, 25-41.

Gross, J. J. (2014). Emotion regulation: Conceptual and empirical foundations.

Gross, J. J., \& John, O. P. (2013). Individual differences in two emotion regulation processes: implications for affect, relationships, and well-being. Journal of Personality and Social Psychology, 85(2), 348.

Gunarsa, S. D. (2018). Psikologi perkembangan anak dan remaja. BPK Gunung Mulia.

Hurlock, E. B., Istiwidayanti, Sijabat, R. M., \& Soedjarwo. (2015). Psikologi perkembangan: Suatu pendekatan sepanjang rentang kehidupan. Erlangga, Jakarta.

Illahi, U., Neviyarni, N., Said, A., \& Ardi, Z. (2018). Hubungan antara kecerdasan emosi dengan perilaku agresif remaja dan implikasinya dalam bimbingan dan konseling. JRTI (Jurnal Riset Tindakan Indonesia), 3(2), 68-74.

Jahja, Y. (2011). Psikologi perkembangan. Kencana.

Lucas, R. E., \& Gohm, C. L. (2016). Age and sex differences in subjective well-being across cultures. Culture and Subjective Well-Being, 3(2), 91-317.

Morris, A. S., Silk, J. S., Steinberg, L., Myers, S. S., \& Robinson, L. R. (2017). The role of the family context in the development of emotion regulation. Social Development, 16(2), 361388.

Mulyati, R. (2017). Kompetensi interpersonal pada anak panti asuhan dengan sistem pengasuhan tradisional dan anak panti asuhan dengan sistem pengasuhan ibu asuh. Psikologika: Jurnal Pemikiran Dan Penelitian Psikologi, 2(4), 43-50.

Muri'ah, S., \& Wardan, K. (2020). Psikologi Perkembangan Anak dan Remaja. Literasi Nusantara.

Nolen-Hoeksema, S., \& Aldao, A. (2016). Gender and age differences in emotion regulation strategies and their relationship to depressive symptoms. Personality and Individual Differences, 51(6), 704-708.

Putro, K. Z. (2017). Memahami Ciri dan Tugas Perkembangan Masa Remaja. Aplikasia: Jurnal Aplikasi Ilmu-Ilmu Agama, 17 (1), 25-32.

Ratnasari, S., \& Suleeman, J. (2017). Perbedaan regulasi emosi perempuan dan laki-laki di perguruan tinggi. Jurnal Psikologi Sosial, 15(1), 35-46.

Rubiani, A. (2017). Perbedaan Regulasi Emosi pada Remaja Ditinjau dari Faktor Usia di Sekolah YPI Swasta Amir Hamzah Medan. Universitas Medan Area.

Rubiani, A., \& Sembiring, S. M. (2018). Perbedaan regulasi emosi pada remaja ditinjau dari faktor usia di sekolah yayasan pendidikan islam swasta Amir Hamzah Medan. Jurnal Diversita, 4(2), 99-108.

Sahputra, D., Syahniar, \& Marjohan. (2017). Kontribusi Kepercayaan Diri dan Kecerdasan Emosi terhadap Komunikasi Interpersonal Siswa serta Implikasinya dalam Pelayanan Bimbingan dan Konseling. Konselor: Jurnal Ilmiah Konseling.

Santrock, J. (2015). Essentials of life-span development. McGraw-Hill Higher Education.

Saputro, K. Z. (2018). Memahami ciri dan tugas perkembangan masa remaja. Aplikasia: Jurnal Aplikasi Ilmu-Ilmu Agama, 17(1), 25-32.

Sari, P., Bulantika, S. Z., Utami, F. P., \& Kholidin, F. I. (2020). Pengaruh Manajemen Stress dan Kelola Emosi Terhadap Tingkat Kecemasan Siswa di Masa New Normal. Bulletin of Counseling and Psycotherapy, 2(2), 62-67.

Seidlitz, L., \& Diener, E. (2018). Sex differences in the recall of affective experiences. Journal of Personality and Social Psychology, 74(1), 262. 
Seputra, I. I. (2020). Pengaruh Tingkat Regulasi Emosi dan Tingkat Relisiensi pada Trauma Tahun Pertama. Jurnal Ilmu Pengetahuan Sosial, 7(2), 408-420.

Silvers, J. A., McRae, K., Gabrieli, J. D. E., Gross, J. J., Remy, K. A., \& Ochsner, K. N. (2017). Age-related differences in emotional reactivity, regulation, and rejection sensitivity in adolescence. Emotion, 12(6), 1235.

Soetjiningsih, C. H. (2018). Seri Psikologi Perkembangan: Perkembangan Anak Sejak Pembuahan Sampai dengan Kanak-Kanak Akhir. Kencana.

Suharsimi, A. (2010). Metodelogi Penelitian. Yogyakarta: Bina Aksara.

Thompson, R. A. (2014). Emotion regulation: A theme in search of definition. Monographs of the Society for Research in Child Development, 25-52.

Umami, I. (2019). Psikologi Remaja. Idea Press Yogyakarta.

WHO. (2015). Core competencies in adolescent health and development for primary care providers: including a tool to assess the adolescent health and development component in pre-service education of health-care providers. World Health Organization.

Zonya, O. L \& Sano, A. (2019). Differences In the Emotional Regulation of Male and Female Students. Jurnal Neo Konseling, 1(3), 1-5. https://doi.org/10.24036/00128kons2019 